\title{
Business Relationships between Corporations and Distributors: A Study of Petroleum Business Law in Indonesia
}

\author{
Budi Santoso*
}

Faculty of Law, Universitas Diponegoro, Semarang, Indonesia

\begin{abstract}
The paper aims to analyze the business relationship in LPG (Liquefied Petroleum Gas) distribution and marketing in Indonesia as it has an important and strategic role for most Indonesian people. By using a juridical and empirical approach, the results showed that Pertamina is a state-owned company that assigns LPG duties to the enduser. To reaches the end-user needed by another intermediary, namely an agent. The legal relationship between Pertamina and the agent is stipulated in the agency contract. Form the theory side, it is necessary to research whether the agency contract is based on the basic principles of agency law or not. The incompatibility of an agency contract with the basic principles of agency law caused the contract not to have legal force. The contribution of this research is its examination of the legal validity of the agency contract of Pertamina with the agent and to provide a legal opinion from the agency theory side which should be the basis for making agency contracts.
\end{abstract}

Keywords: Business Law, Agency, relationship, marketing, oil and gas, Pertamina.

\section{INTRODUCTION}

LPG (Liquefied Petroleum Gas) is a fuel other than oil that meets the criteria as an important commodity and is very much needed to meet the lives of many people. Thus, it is natural that the government considers it necessary to intervene in the issue of distributing these commodities to the end-users, the user community. The regulation made by the government regarding the supply and distribution of LPG is the Regulation of the Minister of Energy and Mineral Resources of the Republic of Indonesia No: 26 of 2009 concerning the Supply and Distribution of LPG, which is equipped with technical regulations in the form of guidelines and procedures for implementing a closed distribution system for certain LPG dated 29 September 2009.

By the provisions of the Minister of Energy and Mineral Resources Regulation No. 26 of 2009, which can organize LPG distribution is a business entity that has obtained an LPG trading business license. Business entities that hold LPG trading business licenses are in charge of carrying out LPG distribution activities. LPG distribution activities are the activities of distributing LPG owned by business entities holding LPG trading business licenses by distributors in the distribution areas designated by Business Entities holding LPG trading business licenses. Meanwhile, distributors are cooperatives, small businesses, and/or national private enterprises appointed as agents by business entities holding LPG trading business

*Address correspondence to this author at the Faculty of Law, Universitas Diponegoro, Semarang, Jl. Prof. Soedarto, Tembalang, Semarang, Central Java 50275, Indonesia; Tel: +62-2476918201; Fax: +62-247691820;

E-mail: budisantoso.fhundip@gmail.com licenses to carry out distribution activities. Based on these provisions, the legal relationship that is built between the business entity holding the LPG trading business license and the distributor is an agency relationship, which of course is outlined in a written agreement.

The distribution of LPG in the country can be grouped into two parts, namely the distribution of general LPG and the distribution of certain LPG. $3 \mathrm{~kg}$ LPG is included in the LPG category with the certain distribution. The distribution of LPG gas in size of 3 kilograms is subsidized by the government. LPG $3 \mathrm{~kg}$ to reach consumers has to go a long way from Pertamina, agents, bases, retailers, to shops. The LPG gas distribution channel is from Pertamina via the LPG Filling Station (SPBE), LPG is distributed to agents who continue distribution to the base. The base must continue distribution to retailers. From retailers, it is possible to sell them to stalls where everyday consumers buy. With this distribution channel, it is very difficult to control prices and supplies to retailers, including indications of price play when people's needs increase, such as coinciding with Eid al-Fitr. From a legal point of view, it is interesting to study the legal relationships of the parties involved in the LPG distribution chain to reach consumers, whether it is based on agency or distributor relationships. Seeing the terminology used by the government is "distribution", this word gives an immediately perceptible impression that the pattern adopted by the government is a legal relationship between distributors and not agencies. However, looking at the parties involved in the LPG distribution chain to reach consumers, especially the legal relationship between the business entity holding the LPG trading business 
license and the distributor appointed as the agent, it can be assumed that the pattern adopted is an agency legal relationship. The main key to ensuring the pattern of legal relationships that occur in the distribution of LPG from Pertamina reaches the consumer, whether the distributor pattern or the agency pattern, is the contract signed by the parties. The legal relationship of the parties is of course stated in the form of a written agreement and from the clauses in the agreement it will be seen whether it is a distributor or agency relationship with any inherent legal consequences.

\section{LITERATURE REVIEW}

\subsection{Principals in Agency Law}

Principals in an agency legal relationship have the right to supervise or control the actions or actions of the agent. The right to exercise principal control is one indicator of an agency relationship. Without the authority of the principal to supervise the agent's actions, the legal relationship is not an agency legal relationship. The relationship between employer and helper, company owner and company employees, is an example of a legal relationship outside the agency. In the Agency Cooperation Contract, Pertamina does not specifically mention the principal's authority to supervise an agent's legal actions in the definition of an agent. The implication is that the definition of an agent that does not mention the principal's authority to supervise or control the actions of the agent is not an agency legal relationship. Legal issues that may arise later from the legal relationship are not agency legal relationships. A contract made based on an agent's formula that does not meet the agent's or agency's requirements is a legally flawed contract. Contracts made are null and void or can be canceled.

In theory, the development of business activities opens opportunities for business actors to strive to achieve their business goals so that to achieve their business goals, business actors can jointly or independently without involving the help of other parties. But nowadays, doing business without the help of other people is something that rarely happens. Typically, business actors need other parties to achieve their business goals (Bowers et al., 2004). Inviting other parties to participate in the achievement of certain business goals, as in the agency format, can also be referred to as partnerships. In the United States legal system, especially in The Uniform Partnership Act (UPA), it is specifically stated that legal provisions relating to the agency are also applied to the provisions of UPA, and partners in partnerships are generally considered to be agents for other partners and for the partnership itself (Schneeman, 1997).

Working together with other parties to achieve certain business goals can be done with two events. First, appointing other people to do certain work for and on behalf of the employer and under the supervision of the employer, this type will be subject to provisions relating to agency rules. Second, by forming a certain business organization, this type will be subject to the provisions relating to the corporation as well as agency law. LPG distribution agency, which is based on a cooperation agreement, is then important to be further examined because agency law defines agency as a relationship between two parties where one party is often referred to as an agent, namely the party who is given the authority to perform actions for and on behalf of and under supervision of other parties, namely the principal. The principal is the party that authorizes the agent to take certain actions and supervises the agent's actions. Meanwhile, the parties that make transactions with agents are called third parties (Santoso, 2015).

Black (1979) defines agency as the relationship between two parties (mainly) as outlined in the form of an agreement or other form, where one party (called an agent) is given the authority to take action on behalf of another person (if this is called the principal) and the agent's actions will bind the principal whether it is because of what is stated in the agreement or caused by the action. The act of a person committing an act on behalf of another person is usually stated in a written letter granting power of attorney or authority or delegation to another party, such as in the relationship between a principal and an agent, between a master and a servant, between an employer and an employee. The agency relationship pattern can be used for individual or corporate interests. The agency relationship can be clearly stated in the contract or not expressly stated in the contract or it can also occur because of the provisions of laws and regulations, where someone gives a delegation to another party to carry out business transactions that are not prohibited by regulations on other parties with little or much authority to exercising discretion in performing delegated acts, the most important of all is that the agent's work is under the supervision of the principal.

\subsection{Principle of Fiduciary Duties in Cooperation Contracts}

In the standard cooperation contract between Pertamina and the agent, it is stated that the definition 
of an agent is an official agent of the first party whose management is fully handled by the second party. This definition does not reflect agency at all, the basic principles that characterize agency do not appear at all. The agent is not a collaborating party but the party receiving the authority or authority from the granting authority (principal). Agents are not partners but are parties receiving power of attorney - the legal relationship is not a legal relationship of cooperation but a legal relationship of granting power of attorney.

That definition is not an agent definition at all. What is given the definition is only a sales agent, but what is an agent is not given the definition. Likewise, matters relating to the basic relationship, namely agency, are not defined at all.

Supposedly, agents are parties/people who receive the authority (authority) to carry out certain legal actions given by the principal to carry out certain legal actions for and on behalf of the principal.

Agency is a legal relationship between two parties, which is usually stated in a written agreement, in which one party (agent) is given the authority to take action for and on behalf of the other person (the principal) is immediately subject to the supervision of the principal.

The implication is that the definition of an agent in the agency cooperation contract of Pertamina - is not an agent and an agency. The legal relationship that is formed is not an agency but maybe a legal relationship between an employer and an employee, an ordinary employment relationship, a master and servant, an employer-independent contractor. Settlement of legal problems that arise cannot be based on agency law.

When someone gives power to others to perform certain actions for and on behalf of the principal and for the benefit of the principal, it will result in a moral obligation to be obeyed by one another. This moral obligation involves two main things, namely trust and confidence. The implication of breaking fiduciary duties can result in the cancellation of contracts. The basic principles of agency relations that give rise to moral obligations of the parties are rooted in the basic philosophy of agency philosophy rooted in the ancient Roman legal tradition, which in Latin: Qui facit per alium facit per se - (He who acts through another acts himself) - whoever commits an act/action through another party is like committing an act/action himself (Hemphill\& Long, 1994). However, this basic principle mentioned does not appear in the definition of an agent in Pertamina's contract with its partners. The implication is that the definition or definition of an agent that is formulated is not classified as an agent or agency relationship, resulting in legal problems that may arise in the future cannot be based on agency law.

\section{METHODS}

This study uses an empirical juridical research approach. Empirical juridical research is legal research on the enactment or implementation of normative legal provisions in action at any particular legal event that occurs in society (Abdulkadir, 2004). According to Schotel (2013), one of the characteristics of juridical law is the autonomous reasoning of a rule that authorizes factual action. This research was conducted by conducting field research at Pertamina and business entities involved in the distribution of LPG until the hands of consumers. The method of thinking used is the deductive method of thinking (a way of thinking in drawing conclusions drawn from something that is general and the conclusion is aimed at something specific).

Based on the perspective of its nature, this study uses a descriptive-analytical approach, meaning that the results of this study attempt to provide a comprehensive, in-depth picture of a state or condition being studied, and then the data obtained is analyzed qualitatively. In connection with the type in this research is juridical empirical, the research is carried out using primary data as the main source and secondary data (Achmad\& Fajar, 2015). According to Soerjono Soekanto (2006), primary legal materials in this study include legal materials in forms of oil and gas law; Minister of Energy and Mineral Resources Regulation No: 26/2009 concerning the Supply and Distribution of LPG along with its technical regulations, Technical Regulations relating to Agency.

The data analysis used in this study is a qualitative normative analysis, in which the data obtained is compiled systematically, then analyzed qualitatively normatively in the form of descriptions, so that conclusions can be drawn to get clarity on the problem under study (Soekanto, 2006). In this study, primary data and secondary data were analyzed and obtained related to the basic principles of agency relations using existing legal norms and theories to describe the implementation of basic principles. In the end, to answer the problems in this study, all data obtained were presented in a qualitative normative manner, namely in the form of a systematic description so that conclusions were drawn (Soekanto, 2006). 


\section{RESULT}

\subsection{Commodity/Product Characteristics}

LPG (Liquefied Petroleum Gas) in Indonesia is better known as the LPG trademark. LPG is a gas fuel consisting of liquefied propane $(\mathrm{C} 3 \mathrm{H} 8)$ and butane $(\mathrm{C} 4 \mathrm{H} 10)$ gas. LPG products are sold by Pertamina to replace the use of fuel oil which has been used more in households and industries. In 2008, the use of kerosene as a fuel in households reached 7.82 million families. In Indonesia, natural gas reserves are far more than petroleum reserves. However, in terms of utilization, it is the opposite. The use of kerosene in the household sector reached $17.35 \%$ while natural gas was only $0.05 \%$. So far, kerosene is a subsidized fuel up to Rp. 48.2 Trillion (2008). For this reason, efforts are made to use natural gas to reduce the burden of subsidies, where the subsidy for natural gas is smaller than the kerosene subsidy.

The Indonesian government has set a kerosene conversion program to LPG through Presidential Regulation No. 104/2007 which regulates the provision, distribution, and pricing of $3 \mathrm{~kg}$ ELLPIJI tabng. The existence of this Presidential Regulation led to the emergence of a new LPG product variant, namely the 3 kg LPG tube. In contrast to other LPG variants whose prices are influenced by world oil prices, the Government determines the LPG $3 \mathrm{~kg}$ price by providing subsidies equal to the difference between the price set by the Government and the price it should be. Due to the subsidies, the price per unit weight of the subsidized $3 \mathrm{~kg}$ LPG variant is cheaper than the $6 \mathrm{~kg}$, $12 \mathrm{~kg}$, or $50 \mathrm{~kg}$ LPG variant.

\subsection{Legal Relations between the Parties in the Distribution of LPG}

The analysis about the pattern of legal relations between the parties in the distribution of LPG, from Pertamina, reaches consumers showed that the oil and gas sector annually contributes more than a quarter of Indonesia's income. On the other hand, the oil and gas sector is also a sector that controls the lives of many people as written in the 1945 Constitution, especially Article 33, where one of the commodities in this sector that is interesting to observe is Liquefied Petroleum Gas (LPG). In the beginning, LPG was marketed by Pertamina to a limited circle with $12 \mathrm{~kg}$ and $50 \mathrm{~kg}$ tube products. However, along with the problems faced in energy supply, where kerosene subsidies are getting bigger and bigger and there is a new national energy policy direction since 2007 the Government has implemented a kerosene conversion program to LPG in the form of $3 \mathrm{~kg} \mathrm{LPG}$. This was done, among other things, to educate kerosene subsidies which were getting bigger and bigger in line with high world oil prices, and then the government replaced them with LPG subsidies which were relatively cheaper. As a result of this subsidy, in the LPG market, a new LPG product variant emerged, namely $3 \mathrm{~kg}$ LPG with a subsidized price which was certainly cheaper than the LPG that was already available in the market, namely LPG 12 and $50 \mathrm{~kg}$ which were more expensive.

In Indonesia, kerosene is indeed more familiar to be used as a household fuel. The price of LPG which is classified as premium makes only a few people use it. Based on its use as household fuel, the use of LPG in Indonesia is still small at around $10 \%$. The majority of Indonesia's population still uses kerosene for cooking (more than $60 \%$ ). Since the beginning, Pertamina launched its LPG product. One of the strategies Pertamina has taken to create LPG consumers is to set a selling price that is below its economic price. Pertamina subsidized the price difference. That way, little by little, consumers began to take shape, especially in urban communities. The initial LPG products issued by Pertamina consist of two types, namely the $12 \mathrm{~kg}$ tube LPG for households and small industries, and the $50 \mathrm{~kg}$ LPG tube for the industrial sector. Although initially LPG was produced to meet household gas fuel needs, it has since grown to meet other needs such as industrial and transportation needs. Broadly speaking, use of LPG as an energy source is used to meet the needs of heat, lighting, and energy sources. Meeting the heat needs of LPG is driven by household needs such as cooking, space heating, and water heating, and so on. This need is what then donates Indonesia's LPG consumption pattern.

\subsection{Distribution and Supply Chain System}

The supply chain system is a set of approaches used to efficiently integrate suppliers, production lines, warehouses/storage places, and outlets/stores so that products can be distributed appropriately in quantity, location, price, and time to minimize overall costs but the level of service satisfaction to customers is still met. In this case, it is related to the supply chain of LPG gas from Pertamina to its final users, namely consumers. As previously stated, in general, the LPG supply chain system is a network that includes various parties, starting from production (inbound) to utilization at the 
consumer level. On the inbound side, LPG is supplied by various sources such as Pertamina refineries, private refineries, as well as through imports from other gas-producing countries. The LPG is then distributed by Pertamina to SPPBE to be put into the $3 \mathrm{~kg}$ LPG gas cylinder. In this case, Pertamina is a single business entity that has the authority to supply the filled LPG which is distributed by the agent to the sub-agent (base). This sub-agent (base) will have the task of distributing LPG cylinders to consumers.

The $3 \mathrm{~kg}$ LPG distribution system is different from the product distribution system in general. This $3 \mathrm{~kg}$ LPG is distributed in a closed system, where the system is controlled by regulations that bind each entity in the supply chain. This system also has certain operating rules and standards by which its implementation is dynamically supervised and controlled. The $3 \mathrm{~kg}$ LPG supply chain system itself is regulated by laws and regulations issued by the Government. Also, each supply chain entity must provide reports on the implementation of distribution to entities that are one echelon level above it. This closed distribution system is implemented because $3 \mathrm{~kg}$ LPG is a product that receives government subsidies so that not all people have the right to receive it. The parties (entities) involved in the supply chain system can be divided into two, namely the supply of raw materials to producers (inbound) and the supply chain from producers to consumers (outbound).

LPG is a hydrocarbon gas that is liquefied with pressure to facilitate storage, transportation, and handling which consists of Propane (C3), Butane (C4), or a mixture of both (Mix LPG) 2. LPG was introduced by Pertamina in 1968. So far it is still much understanding of what and where LPG sources are obtained. According to the literal meaning of the word, LPG stands for Liquified Petroleum Gas, which means gas that is liquefied at a certain pressure is obtained from fractionated petroleum. So that the main source of producing LPG is an oil, not natural gas.

LPG can also be produced from natural gas but requires a more complicated process to process it into LPG. Considering that the main source of LPG comes from crude oil, the largest LPG production is produced from oil fields. In this regard, the factual conditions show that domestic supplies cannot be fully met by domestic supplies. For this reason, efforts must be made to increase domestic LPG production. The increase in LPG production is not only expected from the crude oil field but also LPG production from the natural gas field. One of the efforts made was the enactment of the Domestic Market Obligation (DMO) policy for the Production Sharing Contractor (KPS) of the natural gas field. So far, the potential natural gas production in Indonesia is mostly for export fulfillment. With the DMO policy, it is expected that there will be an increase in LPG production to meet domestic needs.

If the LPG production/drilling process is carried out in Indonesia, the product can be sent directly to the refinery (both Pertamina's and private). Furthermore, if it is obtained through import, the process of shipping from the country of origin to Indonesia is carried out and then stored at the refinery. Furthermore, the LPG from this refinery will be channeled to SPPBE and then put into $3 \mathrm{~kg}$ gas cylinders.

\subsection{Pertamina LPG Agency Contract with Partners}

Several clauses of agency contracts made between Pertamina with partners regarding the appointment of a special LPG distribution agent, which is indicated to be contradictory, are not by the basic principles of agency law are detailed in the following parts. In the agency cooperation contract between Pertamina and the agent stated that the agent is the official agent of the first party whose management is fully handled by the second party.

Article 5 (3) and Article 6 (1) the agency agreement stated that Agents to distribute $3 \mathrm{~kg} \mathrm{LPG}$ to consumers must buy $3 \mathrm{~kg}$ LPG from Pertamina and immediately paid the purchase price of the $3 \mathrm{~kg}$ LPG to Pertamina. Pertamina in this case will deliver $3 \mathrm{~kg}$ LPG following the amount paid by the agent.

Regarding rights and obligations of the parties to the contract, Pertamina has the right to inspect, monitor, and give instructions verbally or in writing to agents, work procedures, administration in LPG sales: has the right to inspect and audit all equipment and equipment of agents, has the right to refuse to deliver LPG gas cylinders if they do not meet the requirements, has the right to impose sanctions if proven gas cylinders do not comply with the applicable requirements, have the right to stop operating the agent if they cannot complete the licensing administration and still have legal problems until there is a permanent legal decision. Pertamina is obliged to provide transport fees to agents as payment for the implementation of LPG distribution. Agents of Pertamina are entitled to a transport fee through a reduction in the purchase price of LPG, after 
implementing the obligations to maintain and be responsible for the quality and quantity of $3 \mathrm{Kg} L P G$, enforce the sale of $3 \mathrm{Kg} \mathrm{LPG}$ ags cylinders directly or through LPG bases, hand over the empty tube to be filled at the Pertamina supply point, serve consumers and the base well, optimally, satisfactorily, maintain smooth Operation, provide counseling, about safety awareness, the safety of using $3 \mathrm{Kg}$ LPG, comply with, pay attention to, implement the provisions and sanctions determined by the first party in the agreement.

The contract states that if an agent commits an act against the law, violation and/or default, then all risks of criminal, civil, and other legal risks are fully the responsibility of the agent and agent to guarantee and release Pertamina of all lawsuits that arise at a later date. Liability for losses suffered by third parties in the agency relationship: - not clearly defined.

\subsection{Obligations of the parties}

Pertamina is obliged to provide transport fees to agents as payment for the implementation of LPG distribution. The contract states the limits of responsibility of the parties in the agency relationship stated that if an agent commits an act against the law, violation, and/or default, then all risks of criminal, civil, and other legal risks are fully the responsibility of the agent and agent to guarantee and release Pertamina of all lawsuits that arise in the future.

The basic principle is that the principal is responsible for losses suffered by a third party for the agent's actions or actions against the third party within the limits of the authority given to him and if the loss suffered by the third party occurs during the execution of the contract. Thus, the indicator for the limit of the parties' responsibility is an act committed by the agent within the limits of the authority granted by the principal to the agent. This indicator should be formulated in the definition of agent or agency as formulated in the Pertamina Agency Cooperation Contract.

The formulation that should be made to show the limits of the responsibilities of the parties in the event of a loss to the third party is to include several formulas relating to the extent of information disclosure about the principal and the form of the contracts they make. For this reason, it is necessary to understand matters relating to the disclosed principal, undisclosed principal, and partially disclosed principal (Cheeseman, 2001; Anderson et al., 1971).
Pertamina's agency contract does not contain details about the practices of terminating the agency relationship, such as the lapse of time, purpose achieved, the occurrence of a specific event, mutual agreement, and termination by one party (Miller \& Jentz, 2011). Moreover, according to Santoso \& Lestari (2018), the termination of agency between the principal and the agent must be notified to the third party who has entered into a legal relationship with the agent, this is often referred to as actual notice or often referred to as a personal notice. Furthermore, the termination of the agency relationship should also be announced through publication media, such as newspapers, this is often referred to as constructive notice. Thus the parties in the agency relationship are entitled to receive notification of the termination of agency activities. Generally, the termination of an agency relationship is due to applicable legal provisions, so no notification to a third party is required. However, if the termination of the agency relationship is due to the actions or actions of the parties in the agency, the agency relationship will continue between the principal and the agent, until notification of the termination of the agency relationship by the principal, which cancels or revokes (revoke) the authority is given to the agent, or notification of termination of the agency relationship comes from the agent, who releases or refuses (renounce) the authority given to him by the principal.

\section{CONCLUSION}

The pattern of legal relations between Pertamina and Agent in distributing LPG from Pertamina and consumers are not an agency relationship, even though the contract signed by the parties is an agency contract, it is more of a distributorship relationship, this is because the underlying legal relationship is a buying and selling relationship and not a power-giving relationship which is the main pillar of the agency relationship. The basic principles of agency law are not reflected and implemented in the agency contract made between Pertamina and Agent, so the contract signed by the parties is not an agency contract but tends to be a distributor contract. Such contracts are legally flawed in a substance that can result in being null and void.

The contribution of this research is its examination of the legal validity of the agency contract of Pertamina with the agent in LPG marketing and distribution and to provide a legal opinion from the agency theory side which should be the basis for making agency contracts. Further research can examine the compliance of the 
two parties to the agreement, and detail the scope of the contract and the characteristics of the business contract for each type of agency. Also, further studies. Further studies are also expected to be able to analyze the agency cooperation agreement between Pertamina and its partners regarding the distribution of LPG to final consumers, especially about patterns, the legal relationship between the parties in LPG distribution from Pertamina. Also, a study of agency legal relationships or distributor relationships is also needed and to examine the basic principles of agency law applied in agency contracts about the LPG supply chain to consumers.

\section{REFERENCES}

Abdulkadir, M. (2004). Hukum dan Penelitian Hukum. Bandung: Citra Aditya Bakti.

Achmad, Y., \& Mukti Fajar, N. D. (2015). Dualisme Penelitian Hukum Normatif \& Empiris. Yogyakarta, Pustaka Pelajar.

Anderson, R. A., Kumpf, W. A., \& Kendrick, R. E. (1971). Business law, principles and cases. South-Western Pub. Co.
Black, H. C. (1979). Blacks Law Dictionary. Paul: West Publishing Company

Bowers, T., Mallor, J. P., Barnes, J., \& Langvardt, A. W. (2004). Business Law, The ethical, global and e-commerce environment. Mc Graw Hill Irwin

Cheeseman, H. R. (2001). Business law: Ethical, international \& ecommerce environment. (Doctoral dissertation, Univerza $\mathrm{v}$ Mariboru, Ekonomsko-poslovna fakulteta).

Hemphill, C. F., \& Long, J. A. (1994). Basic business law. Prentice Hall.

Miller, R. L., \& Jentz, G. A. (2011). Business Law Today: Comprehensive: Text and Cases. Cengage Learning. Nelson Education

Santoso, B. (2015). Keagenan (Agency): Prinsip-Prinsip Dasar, Teori, dan Problematika Hukum Keagenan. Jakarta: Ghalia Indonesia.

Santoso, B., \& Lestari, S. N. (2018). Laporan Penelitian_Prinsip Dasar Hubungan Keagenan Pada Jasa Pengiriman Barang (Studi Hubungan Keagenan di pt. Jalur Nugraha Ekakurir).

Schneeman, A. (1997). The law of corporations, partnerships, and sole proprietorships. Delmar Publishers.

Schotel, B. (2013). Legislation, empirical research and juridical law. The Theory and Practice of Legislation, 1(3), 501-532.

Soekanto, S. (2006). Pengantar penelitian hukum. UI-Press.

Received on 19-01-2021

Accepted on 16-02-2021

Published on 29-03-2021

https://doi.org/10.6000/1929-4409.2021.10.84

(C) 2021 Budi Santoso; Licensee Lifescience Global.

This is an open access article licensed under the terms of the Creative Commons Attribution Non-Commercial License (http://creativecommons.org/licenses/by-nc/3.0/) which permits unrestricted, non-commercial use, distribution and reproduction in any medium, provided the work is properly cited. 